Nowoczesne Systemy Zarządzania

Zeszyt 12 (2017), nr 1 (styczeń-marzec)

ISSN 1896-9380, s. 39-52

Modern Management Systems

Volume 12 (2017), No. 1 (January-March)

ISSN 1896-9380, pp. 39-52
Instytut Organizacji i Zarządzania

Wydział Cybernetyki

Wojskowa Akademia Techniczna

w Warszawie

Institute of Organization and Management

Faculty of Cybernetics

Military University of Technology

\title{
Possibilities of partnership between \\ organizations of public and private sectors \\ - Polish and Lithuanian examples
}

\section{Możliwości partnerstwa między organizacjami w sektorze publicznym i prywatnym - przykłady Polski i Litwy}

\author{
Lina Marcinkevičiūtè \\ Aleksandras Stulginskis University, Lithuania \\ Department of Management and Rural Development \\ Jan Žukovskis \\ Aleksandras Stulginskis University, Lithuania \\ Department of Management and Rural Development \\ e-mail: jan.zukovskis@asu.It \\ Anna Świrska \\ Siedlce University of Natural Sciences and Humanities, Poland \\ Faculty of Economic and Legal Sciences \\ e-mail: annaswirska@gmail.com
}

\begin{abstract}
Partnership of public and private sectors (hereinafter - PPP) has been becoming the object of scientific research more and more frequently in Lithuania and Poland. It is analyzed with regard to various approaches. Similarly to other countries, the demand for investments to improve quality of public services and their development is growing. However, public sector has limited possibilities to allocate sufficient financing for this purpose; therefore new means and possibilities are searched for to achieve these goals. In the authors' opinion, the PPP implementation is still innovation in Lithuania and Poland, although more and more projects have been implemented in the institutions of public sector in cooperation with public sector in attempt to regulate legally the area of contractual relations between the public and private sectors. The article has analyzed theoretical aspects of PPP and presented description of different roles of various interest groups in the PPP process. With regard to the data of theoretical
\end{abstract}


analysis and empiric data, the PPP forms were named and justified, and the practical possibilities of application of the aforementioned forms were suggested.

Keywords: partnership, forms of partnership, public sector, private sector

Abstrakt: Partnerstwo publiczno-prywatne (PPP) jest formą współpracy umożliwiającą intensyfikację rozwoju społeczno gospodarczego. Stało się ono alternatywą dla świadczenia usług publicznych zarówno na poziomie narodowym, jak i lokalnym, a ponadto, w kontekście Polski jest jedną z metod współfinansowania wielu inwestycji samorządowych z zakresu infrastruktury transportowej, energetycznej, czy kulturowo-sportowej. Artykuł przedstawia teoretyczne aspekty funkcjonowania PPP w Polsce i na Litwie, przedstawia dane liczbowe informujące o skali współpracy między sektorem publicznym i prywatnym. Celem artykułu jest przedstawienie istoty PPP w Polsce i na Litwie oraz wskazanie praktycznych rekomendacji dla dalszego istnienia tej formy współpracy międzysektorowej.

Słowa kluczowe: partnerstwo publiczno-prywatne, sektor prywatny, sektor publiczny

\section{Introduction}

The demand for investments to improve quality of public services and their development is growing, both in Poland and Lithuania. However, public sector has limited possibilities to allocate sufficient financing for this purpose; therefore new means and possibilities are searched for to achieve these goals. PPP unites the available resources in order to implement the objectives of public policy and to ensure the quality of public services. The PPP implementation is still innovation in Lithuania, although more and more projects have been implemented in the institutions of public sector in cooperation with public sector; moreover the attempts are made to regulate legally the area of contractual relations between the public and private sectors. In Poland, the cooperation within PPP started in much earlier than in Lithuania and it was a result of political and economical transformation of the state. The shortage of public funds together with the number of tasks of local governments resulted the PPP forms appeared in 90's of XX century, after 1989 (Cenkier, 2006, p. 42). The first piece of legislation that regulated the legal relations of that type was the Act of 27 October 1994 on toll motorways and National Road Fund, under which A1, A2 and A4 toll motorways were built and operated, or just operated, however the first legal act regulating public-private partnership appeared in 2005.

The relevance of the article is stressed by the fact that in presence of totality of the theoretical aspects of PPP, it is important to perceive the causality of this phenomenon related to political, social and economic changes, which force the organizations to review and analyze the missions and visions of their activities, to improve purposefully the set objectives with regard to external changes and internal transformations. It is especially relevant to know the implementation processes of partnership and organization principles of cooperation.

Objective of research - to present the practical recommendations of PPP (case of agricultural company and subjects in eldership). 
Tasks:

1. To analyze the theoretical aspects of PPP forms, both in Lithuania and Poland;

2. To examine the possibilities of partnership between agricultural company (hereinafter - AC) and subjects in eldership in Lithuania.

Object of research - PPP forms.

Research methods - analysis and synthesis of documents and scientific literature, comparative analysis, analysis of data systemization, interview, logical analysis and synthesis, grouping.

\section{Formation possibilities of partnership of the organizations of public and private sectors in theoretical aspect}

The partnership of public and private sectors has been forming in the context of modernization. It is an alternative form of provision of public services and development of infrastructure. In order to ensure the infrastructure or provision of services, the national and local authorities are showing bigger and bigger interest in cooperation with private sector.

"Partnership of public and private sectors" as a legal category has been used in Lithuania since the $16^{\text {th }}$ of June 2009 when the Law on Investments of the Republic of Lithuania was amended and supplemented. In Poland, as mentioned before, PPP became a legal category in 2005, however due to number of flaws and ambiguities new PPP Legal Act was introduced in 2008 (Legal Act on PPP, 19th. Dec. 2008). Together with the Act of 9 January 2009 on concessions for public works or services entered into force. Their purpose was to create a transparent, flexible and effective legal framework of the intersectoral cooperation. Both Acts regulate the PPP agreements between the public and private sectors and set an appropriate standard of functioning of such cooperation for the effective implementation of public tasks.

The definition of partnership explains it as: “...the partnership methods identified in the laws of national or municipal authority and private subject, using which the national or municipal authority transfers the activity assigned to its functions to the private subject, who invests in that activity and necessary assets for certain consideration specified in laws." Certain groups of conception are distinguished in scientific literature (Hodge, 2012; Vičkačkienè, 2010; Greve, 2007; Vaitiekūniené, 2006 et al.), according to which the partnership of public and private sectors may be analyzed as an institutionalized cooperation, in the course of which public goods are created jointly and the activity-related risk is shared; as a long-term contract for infrastructure, which sets strict requirements for final results of the contract; as networks of public policy and management, which stress free interrelations of interested participants; as development of civil society and sociality; and as an urban renewal and economic development. Polish PPP Act defines PPP as "common enterprise 
based on duty and risk sharing between private and public partners". Such definition allows to enumerate the features of Polish PPP (Wolański, 2015, p. 12):

- It refers to infrastructure, that is traditionally provided by the public sector,

- It contains big, up-front investments of public partner in exchange for payments during many years of operation of the project - this feature is essential for financial structure of PPP,

- It allows to transfer some of the risk to the private sector,

- It bases on long-term contracts, closed for the lifetime of the assets.

Thus, the PPP may be understood as a long-term arrangements, obliging private party to conduct and finance infrastructure construction and maintenance works, based on risk sharing between public and private sectors.

It is an often case when the governments implement reforms directed to public needs while solving such public tasks significant for the society as ecologic safety, maintenance of public order, social welfare, education and other social issues. Besides two partners (organizations of public and private sectors), the project is also affected and affects various groups of interests, which should be taken into account and which possible influence on the project should be identified correctly. Possible different roles of the interest groups are described in the table 1.

The expansion of PPP sector in the legal base of the European Union (hereinafter - EU) is defined by 5 essential documents: 49-56 articles of the EU Treaty, Directive of Concessions, Directives on Public Procurements, Green paper on Public-Private Partnership COM (2004). The PPP issues in Lithuania are regulated by the Law on Investments of the Republic of Lithuania, Rules on preparation and Implementation of Partnership of Public and Private Sectors, etc. (the authors have calculated some 13 legal acts); however the abundance of documents does not mean their effective usage. The recommended PPP forms are described in the table 2. 
Table 1. Role of different groups of interests in PPP process

\begin{tabular}{|c|c|c|}
\hline $\begin{array}{l}\text { Group of } \\
\text { interests }\end{array}$ & Group's role & Possible interest \\
\hline Society & $\begin{array}{c}\text { It expresses opinion about transparency } \\
\text { and usefulness of the PPP decisions, as- } \\
\text { sesses consequences of PPP application, } \\
\text { and influences the decisions on PPP } \\
\text { application }\end{array}$ & $\begin{array}{l}\text { The uninterrupted provision of service } \\
\text { is ensured. Usage of provision of effec- } \\
\text { tive services and service's compliance } \\
\text { with the needs of target groups }\end{array}$ \\
\hline Politicians & $\begin{array}{l}\text { It sets and prioritizes the PPP objecti- } \\
\text { ves, informs society hereof, sets criteria, } \\
\text { how to choose PPP method, approves } \\
\text { the selected PPP method, and forms } \\
\text { legal environment of PPP regulation }\end{array}$ & $\begin{array}{l}\text { The selected method of public pro- } \\
\text { curements for selection of partner } \\
\text { has to be protected from corruption, } \\
\text { criminal activity and poor quality } \\
\text { of service }\end{array}$ \\
\hline $\begin{array}{l}\text { Management } \\
\text { and employees } \\
\text { of governmen- } \\
\text { tal authority }\end{array}$ & $\begin{array}{l}\text { It identifies specific needs and objectives } \\
\text { of the authority in PPP area, presents im- } \\
\text { portant information and data to the per- } \\
\text { sons suggesting project, project executors } \\
\text { and groups of interests, implements } \\
\text { changes and protects public interest }\end{array}$ & $\begin{array}{l}\text { Maximal income, secured availability } \\
\text { of service, secured acceptability of the } \\
\text { service price, inducement of fair com- } \\
\text { petition, attraction of investors, impro- } \\
\text { vement of social welfare }\end{array}$ \\
\hline Employees & $\begin{array}{l}\text { They attempt to preserve work places and } \\
\text { available social goods (wages, other be- } \\
\text { nefits), they have qualification and know- } \\
\text { ledge necessary to provide the service }\end{array}$ & $\begin{array}{l}\text { Secured fair behaviour with employ- } \\
\text { ees, secured possibilities to pursue } \\
\text { career, increased productivity, effecti- } \\
\text { veness and motivation }\end{array}$ \\
\hline Users & $\begin{array}{c}\text { They inform about desire and ability } \\
\text { to pay for services, express priorities re- } \\
\text { garding quality and volume of services, } \\
\text { identify the advantages and disadvanta- } \\
\text { ges of the available service }\end{array}$ & $\begin{array}{l}\text { Ensured acceptable price of service, } \\
\text { ensured quality and reliability of servi- } \\
\text { ces, ensured reliability and accountabi- } \\
\text { lity of the service provider }\end{array}$ \\
\hline Investors & $\begin{array}{l}\text { They provide feedback regarding at- } \\
\text { tractiveness of various PPP alternatives, } \\
\text { use procurement procedures and rules, } \\
\text { evaluate their transparency and consi- } \\
\text { stency, perform project's analysis, after } \\
\text { which the real offer is made }\end{array}$ & $\begin{array}{l}\text { Ensured stable and transparent legal } \\
\text { regulation of service, inducement of re- } \\
\text { structuring of organization of public } \\
\text { service provision in order to achieve } \\
\text { higher effectiveness of activity, gene- } \\
\text { ration of new investment possibilities, } \\
\text { and provision of qualified specialists }\end{array}$ \\
\hline
\end{tabular}

Source: own study 
Table 2. PPP forms

\begin{tabular}{|c|c|}
\hline Form of partnership & Characteristic \\
\hline Joint venture & $\begin{array}{r}\text { Public and private sectors establish joint venture in order to gain benefit } \\
\text { for both parties participating in the project }\end{array}$ \\
\hline Public contracts & $\begin{array}{r}\text { Contract of public procurement of works; contract of public procurement } \\
\text { of goods; contract of public procurement of services }\end{array}$ \\
\hline Concession & $\begin{array}{c}\text { Private sector gives funds for development of infrastructure (public con- } \\
\text { cession of works, public concession of services) }\end{array}$ \\
\hline $\begin{array}{c}\text { Privately financed } \\
\text { investment project }\end{array}$ & $\begin{array}{c}\text { Public sector sells part of the organization (the State preserves the agreed } \\
\text { percentage of shares in order to maintain control of provision of part } \\
\text { of the services to society) or entire organization to private investors } \\
\text { blic property (hospitals, schools, etc.). The public sector pays regular fee } \\
\text { to private organization when the property is used (e.g., for 20-35 years). } \\
\text { In the end of the period the property is returned to the State }\end{array}$ \\
\hline $\begin{array}{c}\text { Research of trade } \\
\text { market }\end{array}$ & $\begin{array}{c}\text { The private subject inspects how the market reacts to certain product } \\
\text { or service that the public sector is to make/provide. It is important } \\
\text { in order to decide whether it is meaningful to introduce the product } \\
\text { to the market and to evaluate its demand }\end{array}$ \\
\hline $\begin{array}{c}\text { Application of private } \\
\text { sector's methods for } \\
\text { public subjects }\end{array}$ & $\begin{array}{c}\text { For example, rationalization of employees' motivation scheme, manage- } \\
\text { ment and usage of resources }\end{array}$ \\
\hline
\end{tabular}

Source: own study on the basis of INTOSAI Working Group, 2009

Although the Lithuanian institutions of public sector have been implementing more and more projects recently, they are still considered innovation and it is still attempted to regulate legally the area of contractual relations between such partners. There is no PPP specific law in Lithuania. The implementation of the PPP projects is stopped by the society's distrust in joint projects of the sectors. This is caused by lack of information about such projects and their benefit for society. The authors present the number of PPP contracts under implementation in municipalities as an example. According to the research data, $34 \mathrm{PPP}$ contracts are under implementation in 22 municipalities, where 32 are concession contracts and 2 are the contracts of partnership between authority and private sector (hereinafter - PAPS). It should be noted that 2 new PPP contracts were signed until the $01^{\text {st }}$ of January 2015 ( 1 concession and 1 PAPS contract), but neither of them came into effect in the year 2014. These contracts were made by municipalities of Kaunas city and Vilnius city. The distribution of PPP contracts according to the areas is described in the table 3. 
Table 3. Distribution of contracts of private-public sectors according to the areas

\begin{tabular}{|c|c|c|c|c|c|c|}
\hline \multirow{2}{*}{ Contract's area } & \multicolumn{2}{|c|}{$\begin{array}{l}\text { PPP contracts under } \\
\text { implementation (until the } \\
01^{\text {st }} \text { of January 2015) }\end{array}$} & \multicolumn{2}{|c|}{ Contracts made in 2015} & \multicolumn{2}{|c|}{$\begin{array}{l}\text { Total number of PPP } \\
\text { contracts made before the } \\
01^{\text {st }} \text { of January } 2015^{\star}\end{array}$} \\
\hline & $\begin{array}{l}\text { Number } \\
\text { of concession } \\
\text { contracts }\end{array}$ & $\begin{array}{c}\text { Number } \\
\text { of PAPS } \\
\text { contracts }\end{array}$ & $\begin{array}{c}\text { Number } \\
\text { of concession } \\
\text { contracts }\end{array}$ & $\begin{array}{l}\text { Number } \\
\text { of PAPS } \\
\text { contracts }\end{array}$ & $\begin{array}{l}\text { Number } \\
\text { of concession } \\
\text { contracts }\end{array}$ & $\begin{array}{c}\text { Number } \\
\text { of PAPS } \\
\text { contracts }\end{array}$ \\
\hline Waste usage, recycling and management & 10 & & & & 11 & \\
\hline $\begin{array}{l}\text { Energy, including generation, transfer, } \\
\text { distribution and provision of thermal and } \\
\text { electric energy, oil and natural gas }\end{array}$ & 8 & & & & 8 & \\
\hline $\begin{array}{l}\text { Roads, bridges, tunnels, parking and other } \\
\text { transport infrastructure }\end{array}$ & 4 & 1 & & & 4 & 1 \\
\hline $\begin{array}{l}\text { Cultural, sport, entertainment objects, } \\
\text { devices and other infrastructure }\end{array}$ & 9 & & & & 9 & \\
\hline Health systems & 2 & & & & 2 & \\
\hline Telecommunication infrastructure & & & & & 6 & \\
\hline $\begin{array}{l}\text { Tourism objects, devices and } \\
\text { other infrastructure }\end{array}$ & & & & & 1 & \\
\hline Port and quays infrastructure & & & & & 1 & \\
\hline Public transport infrastructure & & & 1 & & 2 & \\
\hline Educational infrastructure & & 1 & & & & 1 \\
\hline Other infrastructures & & & & 1 & & 1 \\
\hline \multirow{2}{*}{ In total } & 32 & 2 & 1 & 1 & 44 & 3 \\
\hline & \multicolumn{2}{|c|}{34} & \multicolumn{2}{|c|}{2} & \multicolumn{2}{|c|}{47} \\
\hline
\end{tabular}

* - all the valid and already invalid PPP contracts made before the $01^{\text {st }}$ of January 2015 are included into this number Source: Own study on the basis of Ministry of Finance, 2016 
In total $47 \mathrm{PPP}$ contracts were made and $140 \mathrm{mln}$. euros were invested before the $01^{\text {st }}$ of January 2015. In 201416 euros were invested - the major share of investments of PPP capital was attributed to construction of Palanga bypass. According to the research data, the payments made to private subjects during the accounting year 2014 made $11 \mathrm{mln}$. euros, while the subjects of public sector received income of $4 \mathrm{mln}$. euros.

The presence of public-private partnerships as a form of implementation of various projects is visible in many areas of public economy in Poland. The PPP model is used in the district heating sector, transportation, water and wastewater, waste management, sport and recreation, road infrastructure, economy, housing, healthcare, education and science, to the revitalization of green areas and so on. However, during the period of access to European funds, local governments in a limited way seek other sources of funding in recent years. Thus the PPP might reveal its potential as soon as the European funds become dwindling (http://budownictwo.wnp.pl).

The market of PPP in Poland is still developing and collecting experiences. Arguments, that allow for such statement are: a small percentage of PPP contracts in relation to the number of published proceedings, very large diversity of sectors where the attempts of PPP projects implementing are made, as well as the low value of the implemented projects (Cieślak, 2014, p. 310). The table 4 presents the number of PPP contracts in years 2009-2016, that may confirm above mentioned views that the PPP market is not sufficiently developed and there is a need to encourage private investors to increase their capital commitment in the performance of public tasks.

Table 4. PPP contracts signed according to the areas in Poland in years 2009-2016

\begin{tabular}{|c|c|c|c|}
\hline Contract's area & $\begin{array}{c}\text { Total number of PPP } \\
\text { contracts made before } \\
\text { the 2015 }\end{array}$ & $\begin{array}{c}\text { Contracts } \\
\text { made in 2015 }\end{array}$ & $\begin{array}{c}\text { Contracts } \\
\text { made in 2016 }\end{array}$ \\
\hline Waste usage, recycling and management & 5 & 0 & 0 \\
\hline $\begin{array}{c}\text { Energy, including generation, transfer, } \\
\text { distribution and provision of thermal } \\
\text { and electric energy, oil and natural gas }\end{array}$ & 12 & 4 & 0 \\
\hline Culture & 4 & 0 & 2 \\
\hline Health systems & 3 & 0 & 0 \\
\hline Telecommunication infrastructure & 5 & 6 & 0 \\
\hline Sport and tourism & 14 & 7 & 1 \\
\hline Transport infrastructure & 13 & 0 & 1 \\
\hline Educational infrastructure & 5 & 3 & 0 \\
\hline Water and sewage management & 8 & 1 & 1 \\
\hline Other infrastructures & 8 & $\mathbf{2 5}$ & $\mathbf{6}$ \\
\hline In total & $\mathbf{7 7}$ & & \\
\hline
\end{tabular}

Source: own study on the basis of http://www.ppp.gov.pl/ (4.11.2016) 
In 2015 the number of contracts is 25 , and the hightest interests in this matter appears in sport and toutrism area, both in 2015 and during the whole period of functioning PPP in Poland. A specific feature of Polish PPP market, as seen in the table above, is a large variety of its contract areas. In countries with well-established PPP as part of the investment policy is visible far greater concentration - partnership mode is most often used in only a few areas, especially in public services, transport, education, health care and public safety. In the case of Polish broad spectrum of sectors in which a PPP instrument is used means that this market has been emerging (http://www.pi.gov.pl).

\section{Formation possibilities of partnership of the organizations of public and private sectors in practical aspect}

Regarding the practical aspect of PPP in Poland, the PPP Act defines two options for selecting the private partner: 1) according to public procurement law or 2) concession law. The amendment of the Act of May 2010 added a third path of selection of the private partner - the mode of competition based on the provisions of the Civil Code.

Also, the Act defines the activities which may be undertaken within public-private partnership: there are such projects as: construction or refurbishment of a building or structure; provision of services; performance of a work, in particular equipping an asset with devices increasing its value and use; other consideration (service) - combined with maintenance or management of the asset that is used for implementation of the public-private partnership project or related to it.

According to the research data, various PPP forms are implemented in both in Poland and Lithuania. Some of them are regulated in general and some in special legal acts. The fact that the PPP definition has not been yet provided in the legislation of the Republic of Lithuania (hereinafter RL), the PPP forms (sorts) have not been determined in complex way and that the requirements are set for formation and implementation of each of them causes risk that the partnership projects important for society and the State will not be implemented due to lacking regulation; if they are implemented, the public interest will not be represented properly; or the subjects of public sector, who are implementing such projects, will apply unsuitable legal acts, which would regulate not PPP or not the right forms of PPP.

According to the analyzed RL legal acts: RL Law on Concession (2003), RL Law on Amendment and Supplement of the Law on Concessions and Local Self-Government (2006, etc.), and with regard to the works of the researchers (Šutavičiené, 2011, Dūda, 2010 et al.) in the area of partnership of private-public sectors in Lithuania, it is possible to state that as social, economic and other changes are taking place in the country and as the high need for the PPP projects exists, it is very important 
to evaluate the PPP interests and possibilities at certain time and in certain territories so that the aforementioned projects could become important factors promoting the domestic economy.

In order to evaluate the present PPP situation in Lithuania in various areas of probable partnership, the pilot research was conducted on the partnership of AC and subjects of the same eldership (gymnasium, nursery-kindergarten, cultural centre, community centre), in the course of which the cases of possible partnership forms were analyzed, and suggestions, how to solve the present problem were made. The research was conducted in 2011-2015. According to the research data, the analysis of the possible PPP forms between AC and subjects in the same eldership is described in the table 5. The signs of plus and minus are used in the table to mark the possibilities of partnership forms between representatives of private and public sectors.

Table 5. Analysis of possible PPP forms between AC and other subjects of the eldership

\begin{tabular}{|c|c|c|c|c|c|}
\hline & \multicolumn{4}{|c|}{ Possible partnership with AC } \\
\hline & & Gymnasium & Nursery-kindergarten & $\begin{array}{c}\text { Cultural } \\
\text { centre }\end{array}$ & $\begin{array}{l}\text { Community } \\
\text { centre }\end{array}$ \\
\hline \multirow{7}{*}{ 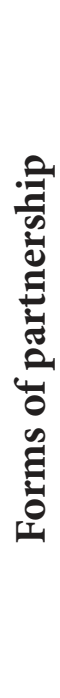 } & Concession & + & + & + & + \\
\hline & Joint venture & + & + & + & + \\
\hline & Privatization & + & + & + & + \\
\hline & Franchise & - & - & - & - \\
\hline & $\begin{array}{l}\text { Privately financed } \\
\text { investment project }\end{array}$ & - & - & - & - \\
\hline & $\begin{array}{l}\text { Research of trade } \\
\text { market }\end{array}$ & - & - & - & - \\
\hline & $\begin{array}{c}\text { Application of } \\
\text { private sector's } \\
\text { methods for public } \\
\text { subjects }\end{array}$ & - & - & - & - \\
\hline
\end{tabular}

Source: own study

It should be noted that $\mathrm{mp}$ formal PPP has been present in the analyzed territory. This territory was chosen for the research following application of both parties (AC and subjects in the eldership). The practical suggestions for PPP are presented on the ground of theoretical and practical researches.

1. Concession between AC and gymnasium and nursery-kindergarten. Panevėžys regional municipality, where Smilgiai gymnasium and nursery-kindergarten are located, could transfer the management services of thermal economy of the gymnasium and nursery-kindergarten to AC (private investor), who would undertake to ensure activity of the thermal economy 
of the gymnasium and nursery-kindergarten, qualitative and proper thermal supply, generation and transfer in the gymnasium's building, to maintain hygienic requirements of heat and hot water in the premises of gymnasium and nursery-kindergarten during the entire calendar year, to supply fuel to the boiler room at its own expenses, to supply qualified staff, to maintain the heating systems of gymnasium and nursery-kindergarten, to renew and modernize thermal economy of gymnasium and nursery-kindergarten using the model of partnership of private and public capital, and at the same time to ensure social and economic benefit. AC makes this contract having the long-term business interest to ensure supply of services and receipt of benefit from investments to $\mathrm{AC}$ as an investor.

2. Concession between $A C$ and cultural centre. The concession contract may be concluded regarding permit to AC to engage in economic-commercial activity related to the management, usage, expansion and maintenance of Smilgiai Cultural Centre, provision of public services in the area of culture, sport, tourism and leisure, while AC would undertake to implement any economic activity, certain rights and duties, and assume the risk related to such activity. For example, AC puts Smilgiai ethnographic homestead that belongs to the cultural centre in order. In such a way, the investments of AC into the object would grant it the right to organize various events in the ethnographic homestead.

3. Concession between $A C$ and community centre. AC invests into clearing-up of the park of Smilgiai town. The mass events organized by eldership, non-governmental organizations, other public institutions and organizations are held in the park. They are important for the town's community and glorification of Panevėžys city. Usually such events are free.

4. When the organizations make contract of joint activity, almost in any area they cooperate their property, work or knowledge and commit for joint objective or activity. The objective of the activity and contribution of each partner is usually indicated in the contract (e.g., funds, property, work or knowledge), limits of mutual responsibility and rules of profit distribution. When the possible partnership of joint activity is analyzed, it is possible for AC, gymnasium, nursery-kindergarten, cultural centre and community centre to establish joint venture, where AC would have 60 percent, gymnasium 10 percent, nursery-kindergarten - 10 percent, cultural centre - 10 percent, and the community centre -10 percent of votes. All the organizations make the contract, whereby they agree to make all the decisions related to the established company together. In such a way the organizations with 10 percent of votes would be the partners and AC would act as an investor. Usually in the joint activity the public sector takes care about the permits, consents, preparation of documents or property, while the private sector 
contributes by financing, knowledge and reputation. According to the Law on Management, Usage and Disposal of National and Municipal Property of the Republic of Lithuania (2012), the legal person of mixed capital is established to implement certain activity and the national and municipal property is invested as the contribution of public sector to the capital of joint venture. According to this law, the representatives of private and public sectors in the eldership cam form the partnership of joint activity and implement together the projects of public interest.

5. Another possible form of partnership is privatization, which provides sale of the property that belongs to the public sector or shares of undertaking controlled by it to private investors, AC in the case in question. It is possible to state that the eldership wants to create favourable conditions for the implementation of public-private partnership projects, because these projects would allow implementing at least part of the plans, how to improve eldership's welfare. The communities unite their members for joint works in order to create welfare of their residential localities and to foster the spiritual and cultural needs of residents for their leisure. The communities gather people, help to solve social, economic, cultural and other problems, carry out cultural, sport and educational activities, and organize various events and trips. Besides, this analysis confirmed that it would be the most meaningful to promote such areas in the eldership as creation and renewal of recreational spaces in Smilgiai eldership and modernization of services provided to the eldership's residents.

PPP is one of the most innovative implementation forms of the projects, which would be desired by public and private sector. Upon generalization of the research data it may be concluded that the projects of this type lack information spread and knowledge necessary for implementation of the projects. The private and public sectors agree both that the most beneficial type of the projects would be the projects of mutual benefit, because both parties participating in the project are equally interested in successful implementation of the project. The risk distributed equally and conducted negotiations are indicated as the most important factors in the questionnaires of the respondents, which would determine successful implementation of projects. The effectively used resources, negotiations of the parties and society's attitude with regard to PPP expansion are especially important for both parties of the project. The risk distribution is very important for both - private and public sectors.

To summarize, it is possible to state that PPP is an exclusive area, so it is very important to spread information about positive examples of such partnership as widely as possible. The most suitable PPP form has to be chosen with regard to the project's type, needs and sector. The type (form) of partnership of public and private sectors is selected upon having assessed these criteria, distribution of performance risk, the person, from whom the private partner receives consideration, and upon having 
determined the participation degree of public sector. The fundamentals of mutual cooperation have to be set already in the early stage of partnership's formation the objectives, motives, value orientations, and attitude to the partnership of public and private sectors and its implementation directions of the participants have to be learnt.

\section{Conclusions}

1. The fact that the PPP definition has not been yet provided in the legislation of the Republic of Lithuania (hereinafter RL), the PPP forms (sorts) have not been determined in complex way and that the requirements are set for formation and implementation of each of them causes risk that the partnership projects important for society and the State will not be implemented due to lacking regulation; if they are implemented, the public interest will not be represented properly; or the subjects of public sector, who are implementing such projects, will apply unsuitable legal acts, which would regulate not PPP or not the right forms of PPP.

2. The type (form) of partnership of public and private sectors is selected upon having assessed these criteria, distribution of performance risk, the person, from whom the private partner receives consideration, and upon having determined the participation degree of public sector.

3. The practical suggestions for PPP are presented on the ground of theoretical and practical researches (AC and subjects in the eldership): concession between $\mathrm{AC}$ and gymnasium, nursery-kindergarten, and cultural centre. When the possible partnership of joint activity is analyzed, it is possible for AC, gymnasium, nursery-kindergarten, cultural centre and community centre to establish joint venture.

4. Cooperation between the public and private sectors brings benefits for both parties, but the biggest beneficiary is the society. In case of Poland, it is worth working out a solution for using UE funds as a financing of PPP investments, so that UE funds were not a competition but support for PPP investments. What is more, the very important issue concerns the encouraging local governments for implementing PPP as a tool supporting regional and local development.

\section{BIBLIOGRAPHY}

[1] Cenkier A., 2006, Partnerstwo publiczno-prywatne jako forma finansowania zadań publicznych, „Studia i Prace Kolegium Zarządzania i Finansów SGH”, Zeszyt nr 70.

[2] Cieślak, R., 2014, Partnerstwo publiczno-prywatne. 100 pytań, wyjaśnień, interpretacji, Lex a Wolters Kluwer business. 
[3] Dūda M., 2010, Theoretical Aspects of the Implementation of Public-Private Partnership, (online) Public Policy And Administration, No. 33, pp. 139-151.

[4] Hodge G., Greve C., 2007, Public-Private Partnerships: An International Performance Review, Vol. 67, Issue 3.

[5] Legal Act on PPP, 19th. Dec. 2008, JoL 2014 r. item. 1146.

[6] Resolution of the Government of the Republic of Lithuania of 25 February 2009 No. 189 On adoption of Implementing Measures for the Implementation of the Program 2008-2012 of the Government of the Republic of Lithuania, Official Gazette, 2009, No. 33-1268.

[7] ŠUtAVIČIENĖ Ž., 2011, The concept of public-privat partnerships in Lithuania, (online) SociETAL Studies, 3(1).

[8] Wolański M., 2015, Public-Private Partnership Project Management, SGH, Warsaw.

\section{ELECTRONIC SOURCES}

[9] Audit, http://audit.gov.ru/en/activities/international-activities/intosai-working-group-on-keynational-indicators/ (2.10.2016).

[10] Budownictwo, http://budownictwo.wnp.pl/warbud-partnerstwo-publiczno-prywatne-wychodziz-cienia,283766_1_0_0.html. (5.11.2016).

[11] EUR-LEX, http://eur-lex.europa.eu/legal-content/EN/TXT/?uri=URISERV\%3Al22012 (10.10.2016).

[12] INFOLEX, http://www.infolex.lt/portal/start_ta.asp?act=doc\&fr=pop\&doc=65125 (20.10.2016)

[13] PPP4KRAKOW, http://ppp4krakow.net (4.11.2016).

[14] PPP.WORLDBANK, https://ppp.worldbank.org/public-private-partnership/library/lithuanialaw-concessions (10.10.2016).

[15] PI http://www.pi.gov.pl/parp/chapter_86196.asp?soid=9CEF7FB614EF40AABE7843209BCB 5A50 (4.11.2016).

[16] INTOSAI Guidelines on Best Practice for the Audit of Risk in Public/PrivatePartnership http:// www.intosai.org/issai-executive summaries/view/article/issai-5240-guideline-on-best-practicefor-the-audit-of-risk-in-publicprivate-partnership-ppp.html.

[17] VaitiekūNienė D. (2006), Public-private partnerships: the present and the future perspectives in Lithuania. Lietuvos Respublikos Finansų ministerija [interactive]. Vilnius 06-08-2006. $<$ http://209.85.129.132/search?q=cache:jR1WQHd8x24J. (04.10.2009).

[18] VIČKAČKIENĖ A., 2010, Implementation of public-private partnership projects in Lithuania: the legal and administrative system. [interactive]. <www.tm.lt/dok/Finmin_vies_privat_partnerLT. ppt>. (15.06.2010). 